Paweł SZKOŁUT

(Łódź, UŁ)

\title{
SCENY MĘCZEŃSTWA I OCALENIA W PÓŹNOANTYCZNEJ SZTUCE SYNAGOGALNEJ*
}

Jak niemal powszechnie wiadomo, historia narodu żydowskiego, trwająca ponad trzy i pół tysiąca lat, była wypełniona tragicznymi wydarzeniami, które stanowily przyczynę cierpienia i śmierci milionów Żydów. Spowodowały one z jednej strony wiele przypadków ich męczeństwa, a z drugiej ocalenia. W czasach starożytnych, począwszy od okresu niewoli egipskiej poprzez najazdy Asyryjczyków w VIII wieku, zniszczenie Jerozolimy w VI wieku przez Babilończyków i uprowadzenie mieszkańców królestwa Judy do niewoli, poprzez prześladowania Żydów w II wieku, którego skutkiem była resurekcja Machabeuszy, czy wreszcie poprzez powstanie żydowskie w I wieku zakończone zburzeniem Świątyni oraz tragicznej w skutkach rebelii Bar Kochby w II wieku - historia wycisnęła $\mathrm{z}$ tego narodu mnóstwo krwi, potu i lez ${ }^{1}$.

Wedle tradycji biblijnej pierwszym męczennikiem w historii był Abel, zabity przez swojego brata Kaina z zazdrości o Boże błogosławieństwo ( $\mathrm{Rdz} 4,1$ 16). Kolejny typ męczennika stanowił Izaak, którego ojciec Abraham miał poświęcić w ofierze. Chociaż ostatecznie nie uczynił on tego, Izaak wedle najstarszej tradycji gotów był dobrowolnie ponieść męczeńską śmierć, aby spełnić ofiarę wobec Boga ${ }^{2}$. Rysy męczeństwa wystąpily też w życiu najmłodszego syna Jakuba - Józefa. Najpierw został on podstępnie sprzedany przez swoich braci i jako niewolnik trafil do Egiptu, a tam przez intrygę żony swojego pana trafił na dwa lata do więzienia ( $\mathrm{Rdz} 37-41)$.

Męczeński los spotkał także wielu z proroków izraelskich, którzy byli prześladowani zarówno przez swoich rodaków, jak i przez obcych. Ze względu na swoje prorockie powołanie cierpiał prorok Izajasz (VIII wiek), który wedle

\footnotetext{
* Artykuł ten stanowi przedmiot referatu na VI Sympozjum Kazimierskim (3-5 V 2002) pt. „Męczennicy w świecie późnego antyku”.

${ }^{1}$ Por. H. Graetz, Historja Żydów, I-IV, thum. S. Szenhak, Warszawa 1929 (reprint Kraków 1990); J. Bright, Historia Izraela, thum. J. Radożycki, Warszawa 1994; P. Johnson, Historia Żydów, tłum. M. Godoń - M. Wójcik, Kraków 1990.

2 Por. B. Goldman, Sacred Portal, Washington 1966, 55n; Midrash Rabbah, red. I. Epstein, London 1939, LVI 8.
} 
żydowskiej tradycji poniósł męczeńską śmierć ${ }^{3}$. Żyjący na przełomie VII/VI wieku prorok Jeremiasz był wielokrotnie więziony, zaś Daniel przebywający na wygnaniu w Babilonii został za swoją wierność wrzucony do jaskini z lwami, skąd wyszedł cało dzięki Bożej interwencji (Dn 6, 17-29). Księga Daniela opisuje również przypadek trzech młodzieńców: Ananiasza, Azariasza, Michaela przebywających w kraju Chaldejczyków w tym samym czasie co $\mathrm{Da}$ niel, którzy ze względu na posłuszeństwo swojej religii i nieoddanie czci złotemu posaggowi, zostali wrzuceni do rozpalonego pieca, skąd uratował ich aniol Boży (Dn 3, 8-97). W księgach Machabejskich czytamy też o męczeństwie Żydów w czasach panowania Antiocha Epifanesa IV, jak bohatersko oddawali swoje życie w imię wiary w Boga i wierności Jego Prawu (1 Mch 1, 41-64). $\mathrm{Z}$ kolei w Ewangeliach Jezus piętnując uczonych w Piśmie wspomniał jeszcze o innych prorokach, którzy ponieśli męczeńską śmierć $\mathrm{z}$ rąk swoich pobratymców, a wśród nich wymienił np. proroka i kaplana Zachariasza ${ }^{4}$.

Zaistnienie zjawiska męczeństwa $\mathrm{w}$ historii narodu żydowskiego miało zarówno wymiar duchowy, religijny i teologiczny, jak też społeczny i polityczny. Począwszy od czasów Abla poprzez Izaaka, który stal się symbolem gotowości do poniesienia ofiary $z$ własnego życia, Józefa, który po latach spędzonych w egipskim więzieniu otrzymał najwyższą godność na dworze faraona, największych proroków $w$ historii Izraela, czy poprzez wielu nieznanych $\mathrm{z}$ imienia przedstawicieli tego narodu, którzy w historii swojego życia stali się męczennikami - w większości przypadków za męczeństwem lub gotowością na nie stała przede wszystkim wiara i miłość do Boga, czego praktycznym wyrazem było posłuszeństwo Jego woli i prawu.

Niektórzy spośród wyżej opisanych patriarchów i proroków, którzy dzięki swojej odwadze i poświęceniu byli gotowi na ofiarę i męczeństwo w imię wierności Bogu, zostali dzięki Jego łasce i interwencji ocaleni od zaglady. Tak się stało w przypadku Izaaka, w miejsce którego zostal poświęcony baranek. Również Józef został ocalony, najpierw od śmierci z rąk swoich braci, a potem w Egipcie od długoletniego przebywania w więzieniu. W swoim życiu niejednokrotnie ocalany był prorok Eliasz, Izajasz, Jeremiasz, Ezechiel i Daniel. W okresie perskim za rządów Kserksesa (Aswerusa) ocalony został cały naród żydowski, przeciwko któremu wydany został już wcześniej dekret zagla$\mathrm{dy}^{5}$. Poza tymi znanymi $z$ historii i kart Biblii przypadkami ocalenia wystapily one jeszcze prawdopodobnie $w$ dziejach wielu innych nieznanych nam $z$ imienia ludzi, którzy zostali uratowani od niechybnej śmierci dzięki swojej wierze i pomocy Boga.

${ }^{3}$ Por. Biblia Tysiąclecia, Warszawa 1980, 847; Wielka Encyklopedia PWN, Warszawa 2001, hasło: „Izajasz”; L. Stachowiak, Księga Izajasza, I-II, Warszawa 1996.

${ }^{4}$ Por. Łk 11, $50 \mathrm{n}$. Więcej o bohaterach wiary w historii Izraela zob. Hbr 11.

5 Opisuje to Księga Estery. 
Rozpatrując zjawisko męczeństwa i ocalenia w historii żydowskiej trzeba sobie zadać pytanie: $w$ jaki sposób zostały one wyrażone w sztuce i jakie symboliczne sceny w niej wystąpiły?

Spośród wielu przykładów męczeństwa i ocalenia opisanych w Starym Testamencie, w późnoantycznej sztuce synagogalnej wystąpiły dwa z nich. Pierwsza historia została zobrazowana w scenie ofiarowania Izaaka przez Abrahama, a druga w kompozycji ukazującej proroka Daniela w jaskini lwów. Są to sceny o tyle szczególne, że ich główni bohaterowie: Izaak i Daniel przechodząc w imię wiary przez męczeństwo nie ponieśli śmierci, lecz zostali uratowani i ocaleni przez Boga. Mają one tym samym wielorakie znaczenie dotyczące ofiary, męczeństwa i ocalenia. Inne przedstawienia dotyczące tej ostatniej tematyki pochodzą na przykład z synagogi w Dura Europos ${ }^{6}$.

Ze względu na tematykę tego artykułu zostaną w nim opisane wyłącznie te sceny ze sztuki synagogalnej, które zawierają w sobie jednocześnie przedstawienie męczeństwa i ocalenia. Są to więc kompozycje wyobrażające ofiarę Abrahama i proroka Daniela w jaskini lwów. Pominięte zostaną natomiast obrazy pochodzące z Dura Europos, których głównym tematem jest przede wszystkim ocalenie. Ich prezentacji będzie towarzyszyć nakreślenie występowania tych dwóch głównych scen męczeństwa i ocalenia w sztuce wczesnochrześcijańskiej, włącznie z prezentacją ich analogii do sztuki synagogalnej.

\section{SCENY MĘCZEŃSTWA A SCENY OCALENIA W SZTUCE ŻYDOWSKIEJ}

Opisane powyżej symboliczne „sceny męczeństwa” należą do szerszego gatunku ,scen ocalenia”, obecnych zarówno w sztuce żydowskiej, jak i w dużo większym zakresie w sztuce wczesnochrześcijańskiej. Będąc kompozycjami przedstawiającymi męczeństwo pokazują one jednocześnie ludzkie ocalenie spod władzy cierpienia i śmierci, dokonane za pomocą nadprzyrodzonej, boskiej interwencji. Jak wspomniano już powyżej, zarówno Izaak jak i Daniel mieli z jednej strony status męczenników, a z drugiej zostali ocaleni dzięki boskiej wszechmocy. W przeciwieństwie do wielu proroków i apostołów, którzy ponieśli śmierć za swoją wiarę i miłość do Boga, Izaak i Daniel zostali z niej cudownie uratowani. W historii ofiarowania Izaaka przez Abrahama będącego teologiczną podstawą judaizmu i chrześcijaństwa, ważna była sama gotowość Izaaka do ofiary dla Boga. To uczyniło z niego typ męczennika, który przeżył i został ocalony ${ }^{7}$.

${ }^{6}$ Por. przyp. 9.

${ }^{7}$ Por. C. Jenks, The Akedah Tradition as a Window into early Jewish and Christian SelfUnderstanding, w: Brisbane Colloquium for NT and Early Christian Studies, Brisbane 1996. 
W starożytnej sztuce żydowskiej największy repertuar „scen ocalenia” wystąpił we wspomnianym powyżej programatycznym malarstwie synagogi z Dura Europos, datowanym od 1. pol. II wieku do ok. pol. III wieku ${ }^{8}$. Na zachodniej ścianie tego budynku, obok kompozycji wyobrażającej $\mathrm{m}$. in. ofiarowanie Izaaka, znalazły swoje miejsce inne sceny ilustrujące wydarzenia historyczne związane z ocaleniem. Należy do nich wyobrażenie uratowania Mojżesza z wód Nilu przez córkę faraona, scena zatopienia wojsk egipskich po przejście Izraelitów przez Morze Czerwone oraz ta z księgi Estery przedstawiająca wydanie dekretu przez perskiego króla Aswerusa, który rehabilitował Żydów i anulowal wcześniejszy, godzący w ich życie edykt. Malowidła z synagogi w Dura Europos były inspirowane historiami biblijnymi, jak i tradycją ustną spisaną w Talmudzie, midraszach i rozmaitych dodatkach (Toseftach) ${ }^{9}$. Pod względem ikonograficznym mogly one być natomiast świadectwem istnienia szerszego kręgu sztuki wizualnej, tworzonej przez Żydów z diaspory, gdzie „sceny ocalenia” miały swoje ważne miejsce.

Z wyjątkiem kompozycji przedstawiających ofiarowanie Izaaka i Daniela wśród lwów, w sztuce synagogalnej rzymskiej i bizantyjskiej Palestyny nie wystąpiły (lub nie zostały do tej pory odnalezione) inne sceny męczeństwa i ocalenia. Wyobrażenie ofiary Abrahama wystąpiło na mozaice synagogi z Beth Alfa i Seforis, stanowiąc przykład jednego $z$ wielu tego typu przedstawień w sztuce synagogalnej. $Z$ kolei scena ukazująca proroka Daniela w jaskini lwów pochodzi $z$ trzech miejsc: mozaiki synagogi $z$ Naaran $w$ Judei, reliefu bazaltowego bloku z En Samsam w Golanie i mozaiki synagogi z Susija w Judei. Powyższe kompozycje w polączeniu z Dura Europos poslużą do pełnego przedstawienia fenomenu występowania scen męczeństwa i ocalenia w sztuce synagogalnej późnego antyku.

\section{SCENA OFIAROWANIA IZAAKA PRZEZ ABRAHAMA. IKONOGRAFIA I SYMBOLIKA}

Historia ofiarowania Izaaka przez Abrahama została zapisana w 22 rozdziale Księgi Rodzaju. Czytamy tam, że Abraham wezwany przez Boga do złożenia ofiary ze swojego syna, był do końca posłuszny Jego woli. Wierzył on "siłą absurdu", jak się wyraził S. Kierkegaard, że Izaak zostanie w jakiś

${ }^{8}$ Por. M. Rostovtzeff, Dura Europos and its Art, Oxford 1938; C. Kraeling, The Excavations at Dura Europos, vol. 8: The Synagogue, New Haven 1956; R. Du Mesnil de Buisson, Les Peintures de la synagogue de Doura Europos, 245 -256 aprés J.-C., Paris 1934; E.R. Goodenough, Jewish Symbols in Graeco-Roman Periods, New York 1953-1968), vol. IX-XI; L.I. Levine, The Synagogue of Dura-Europos, w: Ancient Synagogues revealed, red. L.I. Levine, Jerusalem 1981, 172-177.

9 J. Neusner, Judaism at Dura-Europos, w: Early Rabbinic Judaism, red. J. Neusner, Leiden 1975, 188-208. 
sposób ocalony albo w ostateczności na nowo wskrzeszony, gdyż przecież z niego miał się wywieźć naród „liczny jak gwiazdy na niebie i jak ziarnka piasku nad brzegiem morza" ( $\mathrm{Rdz} 22,17)^{10}$. Stąd, gdy Izaak zapytał swojego ojca o jagnię na całopalenie, ten odpowiedział mu, że „Bóg upatrzy sobie jagnię na całopalenie" ( $\operatorname{Rdz} 22,8)$. Ofiarowanie Izaaka miało się odbyć na górze Moria, gdzie później stanęła świątynia Salomona i gdzie wedle aramejskicj wersji Biblii Hebrajskiej (Targum Yeruszalmi) składali wcześniej swoje ofiary: Adam, Abel, Kain oraz Noe i jego synowie ${ }^{11}$. Abraham, zwany „ojcem wiary", wyszedł zwycięsko z próby, jakiej poddał go Bóg. Chociaż w Księdze Rodzaju nie zostało to dosłownie zapisane, tradycja żydowska podkreśla pełne poddanie się Izaaka woli Boga i jego gotowość na poniesienie ofiary. Pisal o tym zarówno Filon z Aleksandrii, Józef Flawiusz, jak i późniejsza literatura rabiniczna $^{12}$. Wedle jednego $z$ midraszy, Izaak miał prosić swojego ojca „aby go związał mocno, tak żeby się nie opierał i żeby mu ręce nie drżały po to, aby jego ofiara była ważna przed Bogiem"13. W tradycji judaizmu, począwszy od czasów późnoantycznych aż po współczesność, ofiara Izaaka (hebr. akedah) stała się ważnym motywem pobożności i mistyki, rodzącym gotowość do poświęcenia swojego życia dla Boga. Izaak zostal w ten sposób figurą Izraela, symbolem jego losu i gotowości na ciągłe ponoszenie ofiary ${ }^{14}$. Natomiast samo związanie Izaaka przez Abrahama tuż przed aktem ofiarowania, miało symbolizować niewolę Żydów wśród obcych narodów i różnorodne ograniczanie ich praw.

1. Ofiarowanie Izaaka na malowidle synagogi z Dura Europos. W umieszczonej na zachodniej, skierowanej w stronę Jerozolimy ścianie synagogi w Dura Europos, zawierającej najważniejsze obrazy malarskie podzielone na trzy rzędy, scena ofiarowania Izaaka zajmowała centralne miejsce (ryc. 51) ${ }^{15}$. Znajdowała się ona po prawej stronie malowidła znajdującego się tuż nad arkadą niszy na Torę. Jego środek wyznacza portal Świątyni, zaś lewą stronę zdobi menora, stojąca na podwójnej bazie, będąca prototypem menory świątynnej.

$\mathrm{Na}$ pierwszym planie kompozycji akedah widoczny jest baranek uwiązany do krzaka. Wyżej stoi Abraham, który jest odwrócony plecami i trzyma w prawym ręku nóż. Oltarz znajduje się wyżej na lewo, a na jego wierzchu leży wygięta postać Izaaka. Na samym szczycie, w prawym rogu został wyobrażony namiot, u którego wejścia stoi jeden ze służących patriarchy. Natomiast u góry,

\footnotetext{
${ }^{10}$ Por. S. Kierkegaard, Bojaźń i drżenie, tłum. J. Iwaszkiewicz, Warszawa 1995, 78nn.

$"$ Por. Goldman, Sacred Portal, s. 56. LVI 8 .

${ }^{12}$ Por. Philo, De Abraham 32-36, Josephus Flavius, Antiquitates XIII 1-4; Midrash Rabbah

${ }^{13}$ Midrash Rabbah LVI 8.

${ }^{14}$ Por. Encyclopaedia Judaica, XVI, New York - Jerusalem 1971, hasło: „Izaak”.

${ }^{15}$ Por. Levine, dz. cyt., s. 175; Goodenough, Jewish Symbols, IX, s.75nn; XI, fig. 66.
} 
bezpośrednio nad ołtarzem, z nieba wynurza się ręką symbolizująca boską interwencję ${ }^{16}$. Księga Rodzaju opisuje to wydarzenie w następujący sposób:

„Potem Abraham sięgnął po nóż, aby zabić swego syna. Ale wtedy Aniol Pański zawolał na niego z nieba i rzekł: «Abrahamie, Abrahamie!». A on rzekt: «Oto jestem». Anioł powiedzial mu: «Nie podnoś ręki na chłopca i nie czyń mu nic zlego! Teraz poznałem, że boisz się Boga, bo nie odmówiłeś Mi nawet twego jedynego syna». Abraham obejrzawszy się poza siebie, spostrzegł barana uwikłanego w zaroślach. Poszedı więc, wziął barana i złożył go w ofierze całopalnej zamiast swojego syna" $(22,10-13)$.

W dekoracji malarskiej zachodniej ściany w Dura Europos istotne było umieszczenie w centralnym miejscu wizerunku portalu Świątyni. Miało to swój związek ze sceną ofiarowania Izaaka, gdyż wedle tradycji akedah miała się odbyć w miejscu, gdzie później stanęła świątynia Salomona - na górze Syjon ${ }^{17}$. Również umieszczenie menory - głównego symbolu judaizmu po lewej stronie portalu, miało swoje głębokie uzasadnienie, stanowiąc bezpośrednie nawiązanie do menory świątynnej.

Generalnie rzecz biorąc, obecność sceny przedstawiającej ofiarę Izaaka w bezpośredniej bliskości niszy na Torę będącej „sercem” całej synagogi, świadczy o jej ogromnej wadze i symbolicznym znaczeniu utrwalonym w świadomości ówczesnych Żydów zamieszkujących rubieże Mezopotamii. Została ona wybrana jako najważniejsza spośród wielu scen biblijnych, a przedstawiając męczeństwo Izaaka i jego ocalenie przypominała Żydom o ich powinności wobec Boga, a także o Jego miłosierdziu.

2. Scena ofiarowania Izaaka na mozaice synagogi $z$ Beth Alfa. W datowanej na VI wiek synagodze $z$ Beth Alfa na południe od Galilei, kompozycja wyobrażająca ofiarę Abrahama znajduje się na samym dole mozaiki podłogowej ${ }^{18}$. Wykonawcy tej niezwykłej mozaiki o ludowym, prymitywistycznym stylu, Marianos i Hanina, podzielili ją tematycznie na trzy części. W panelu dolnym znajduje się scena akedah; partię centralną zdobi krąg z dwunastoma znakami zodiaku z Heliosem na rydwanie w środku i personifikacjami pór roku w rogach; najwyższą część dekoruje zaś portal Swiątyni bądź jej Najświętszego Miejsca (heb. devir), zaś jego boki: dwa ptaki, lwy i menory z pękami gałązek

${ }^{16}$ Wykorzystanie w tej scenie motywu ręki nawiązuje do starożytnej, bliskowschodniej tradycji związanej z jej symbolikę, zarówno w ludzkim, jak i boskim aspekcie. W tym przypadku jest to ręka Boga, symbolizująca Jego moc i opatrzność. Symbolika ręki w różnych aspektach była obecna m.in. w sztuce egipskiej, mezopotamskiej, a na obszarze Palestyny wystąpila np. na pochodzącej z XII wieku prz. Chr. solarnej steli z Hazor, por. J.C. Cooper, An illustrated Encyclopaedia of traditionals Symbols, London 1999, hasło: „hand”.

17 Por. L. Ginzberg, The Legends of the Jews, Philadelphia 1968, 276-285.

18 Por. Goldman, Sacred Portal, photo 1. 
drzewa palmowego, mirtu i wierzby (lulav), owocami cytrusowymi (etrog), szufelkami kadzidlanymi (machta) oraz rogami baranimi (szofar). Na skraju wszystkich paneli mozaiki znajdują się różne motywy geometryczne, roślinne i zwierzęce, zaś samo wejście do synagogi zdobi inskrypcja dedykacyjna, flankowana przez wizerunki lwa i byka (odwrócone do góry nogami).

$\mathrm{Na}$ kompozycję przedstawiającą Abrahama ofiarującego swojego syna składają się: od lewej strony dwie postacie sług patriarchy ciągnących osła, w środku sceny baranek przywiązany do krzaka, a tuż zanim Abraham dzierżący olbrzymi nóz w prawej dłoni, zaś w lewej trzymający małego Izaaka, którego kieruje ku ołtarzowi, pełnemu palących się żertw (ryc. 52). Cała kompozycja jest przedzielona poziomą linią, oddzielającą sferę ziemską od kosmicznej. $\mathrm{Na}$ ich granicy, w samym środku sceny, wynurza się (podobnie jak na malowidle z Dura Europos) Boska Ręka, nad nią natomiast widnieje rząd gwiazd symbolizujących sferę nieba. Nad postaciami Izaaka i Abrahama znajdują się ich imiona, zaś pod Boską Ręką słowa skierowane do Abrahama: „nie podnoś ręki” (na chłopca), a po lewej stronie baranka słowa: ,,i spójrz na baranka”. Wszystkie inskrypcje są wykonane w języku hebrajskim. Charakterystyczny dla tej kompozycji jest frontalizm ludzkich postaci, typowy dla sztuki orientalnej.

Podział mozaiki na trzy części może mieć tu z powodzeniem symboliczne znaczenie. Wchodzący do synagogi napotykali najpierw scenę akedah, która wedle opinii niektórych badaczy, oprócz uniwersalnej symboliki ofiary, mogła także wyrażać sferę ziemi. Następny panel wyobrażający znaki zodiaku i Heliosa symbolizowałby wówczas sferę widzialnego nieba, zaś najwyższy panel $\mathrm{z}$ wyobrażeniem portalu świątynnego, menorami i lwami - boskie, niewidzialne Niebo ${ }^{19}$. Inna interpretacja trzech części mozaiki postrzega ją natomiast jako reprezentację, patrząc od dołu: kapłaństwa, królestwa i Tory ${ }^{20}$.

Scena ofiarowania Izaaka umieszczona na przedzie mozaiki synagogi, widoczna zaraz po wejściu do budynku, oddziaływała siłą swojej symboliki na wchodzących do niej Żydów. $Z$ jednej strony podkreślała ona bezwarunkowe poddanie się woli Boga uczynione przez Abrahama i jego syna, a z drugiej przedstawiała opatrznościowy charakter Jahwe. Była ona doskonałym obrazem zawierającym w swojej treści niektóre $z$ najważniejszych, duchowych przesłań judaizmu.

3. Akedah na mozaice synagogi z Seforis. Kolejny przykład sceny wyobrażającej ofiarę Abrahama pochodzi z mozaiki V-wiecznej synagogi w Seforis

${ }^{19}$ Por. tamże, s. 66.

${ }^{20}$ Por. tamże, s. 67. Z kolei, patrząc na tą mozaikę w świetle mistycyzmu, można ją zinterpretować w następujący sposób: najnizszy panel z ofiarą Abrahama jest symbolem duchowego oczyszczenia człowieka, mozaika ze znakami zodiaku - symbolem jego oświecenia, zaś panel z portalem świątyni - symbolizuje zjednoczenie czlowieka z Bogiem, zob. Goodenough, Jewish Symbols, I, s. 253. 
w zachodniej Galilei ${ }^{21}$. Znajdowała się ona tam w dolnej części hali głównej wspartej na pięciu kolumnach, do której wiodły dwa wejścia $\mathrm{z}$ westybulu. Mozaiki są zachowane częściowo, a oryginalnie pokrywały one całą podłogę synagogi. Budynek jest położony na linii wschód - zachód; jego główny portal znajdował się po stronie południowej, natomiast beth arona (pomieszczenie na Torę), z której zachowała się platforma (bema) była usadowiona przy ścianie zachodniej.

Mozaika głównego pomieszczenia jest podzielona na siedem rzędów zawierających poszczególne części z wyobrażeniem rozmaitych scen i kompozycji, zwieńczonych przez inskrypcje w języku greckim i hebrajskim. Patrząc od góry, w pierwszym rzędzie najbliższym bemie znajdują się trzy panele mozaik przedstawiające wieniec (Tory ?), flankowany przez dwa lwy trzymające w swoich wyciągniętych lapach głowy byków. W drugim rzędzie znajduje się portal Świątyni lub jej Miejsca Najświętszego (devir) z szufelką kadzidlaną (machta) $\mathrm{z}$ przodu, zaś na każdym z jego boków - menora z rogiem baranim (szofar), gałązkami palmy, mirty i wierzby (lulav) oraz owocem cytrusowym (etrog). Trzeci, częściowo zachowany rząd mozaik przedstawia w środku ołtarz z odwróconą postacią Aarona składającego ofiarę; po lewej stronie stoi ogromne naczynie $\mathrm{z}$ wodą wsparte na kolumnie $\mathrm{z}$ jońskim kapitelem, zaś po prawej byk i baran ${ }^{22}$. Jest to scena konsekracji Aarona i jego synów opisana w 29 rozdziale Księgi Wyjścia.

Tematyczna kontynuacja powyższej kompozycji wystąpiła w lewym panelu czwartego rzędu mozaik. Znajdują się tam bowiem motywy barana, dzbana na oliwę, naczynia na mąkę oraz dwie trąby, czyli przedmioty związane z ofiarniczym i ceremonialnym kultem świątynnym. Obok, w środkowej części mozaiki wyobrażony został świątynny stół na chleby pokładne, zaś po prawej stronie kosz z owocami symbolizujący pierwociny owoców składanych corocznie w Świątyni ${ }^{23}$.

Piąta część mozaiki jest największa i przedstawia krąg ze znakami zodiaku, słońcem i rydwanem w środku oraz personifikacjami czterech pór roku wraz $\mathrm{z}$ ich atrybutami $\mathrm{w}$ rogach panelu. W przeciwieństwie do innych synagog, których mozaiki dekorowały podobne zodiakalne kręgi - w Seforis brak jest postaci Heliosa powożącego rydwan; tutaj jego miejsce zajmuje samo słońce ${ }^{24}$.

Szósty rząd mozaiki jest podziclony na dwie części (ryc. 53), a jego tematyka bezpośrednio dotyczy historii ofiarowania Izaaka, zapisanej w 22 rozdziale

${ }^{21}$ Por. Z. Weiss - E. Netzer, The Synagogue Mosaic, w: Sepphoris in Galilee. Crosscurrents of Cultures, red. R. Nagy, Jerusalem 1994, 133-138, fig. 67; tenże, Promise and Redemption. A Synagogue Mosaic from Sepphoris, Jerusalem 1996.

${ }^{22}$ Nad baranem widnieje hebrajska inskrypcja: „Jedno jagnię [...]” pochodząca z Lb 28, 4: „Jedno jagnię ma być złożone na całopalenie rano, a drugie wieczorem" (tłum. z Biblii Tysiqclecia), por. Wj $29,39$.

${ }^{23}$ Por. Księga Kapłańska. 
Księgi Rodzaju, Na lewym panelu widoczni są dwaj słudzy z osłem, pozostawieni przez Abrahama u stóp góry Moria. Prawy panel, niestety w większości zniszczony, przedstawiał pierwotnie samą scenę akedah. $\mathrm{Z}$ całego obrazu zachowało się jedynie wyobrażenie drzewa z przywiązanym do niego barankicm (z którego widoczna jest tylko głowa) oraz dwie pary sandałów: Abrahama i jego syna, które pozostawili na górze. W części centralnej znajdowało się przedstawienic patriarchy ( $\mathrm{z}$ nożem), stojącego nad związanym Izaakiem, który byl umieszczony po prawej stronie przy ołtarzu ${ }^{25}$.

Siódma część mozaiki, leżąca tuż przy wejściu do hali głównej, jest również zachowana w bardzo słabym stopniu. $Z$ jej fragmentów można stwierdzić, że oryginalnie przedstawiała ona scenę wizyty aniołów (w ludzkich postaciach) u Abrahama pod dębami Mamre, którzy zapowiedzieli mu narodziny syna (Rdz 18, 1-15). Byłaby to więc kompozycja poświęcona wydarzeniu poprzedzającym chronologicznie ofiarowanie Izaaka ${ }^{26}$.

Mozaika z Seforis należy do najbogatszych pod względem tematycznym i najlepszych formalnie mozaik synagogalnych okresu bizantyjskiego. Jej tematyka jest ściśle związana $z$ ceremonialnym i ofiarniczym kultem świątynnym. $\mathrm{Z}$ jednej strony wystąpiły tam tematyczne i kompozycyjne podobieństwa do mozaik innych synagog (np. z Hammat Tiberias i Beth Alfa), do malowideł z Dura Europos (np. w scenie konsekracji Aarona na arcykapłana), a z drugiej do niektórych mozaik chrześcijańskich, zwłaszcza z prezbiterium kościoła San Vitale w Rawennie ${ }^{27}$.

${ }^{24}$ Interpretacją znaków zodiaku na mozaikach synagogalnych podjęła się m.in. R. Hachlili, The Zodiac in ancient Jewish Art: representation and significance, „Bulletin of the American Schools of Oriental Research" 228 (1977) 62-77.

${ }^{25}$ Podobnie jak na mozaice prezbiterium kościoła $z$ San Vitale w Rawennie.

26. Analogiczna scena wystąpila na mozaice z San Vitale.

${ }^{27}$ Por. F.W. Deichmann, Früchristliche Bauten und Mosaiken von Ravenna, Baden-Baden 1958. W tradycji chrześcijańskiej scena ofiarowania Izaaka przez Abrahama stanowi nieodłączny element kanonu sztuki. Podstawa tego tkwi w teologii chrześcijańskiej, wedle której Izaak jest typem Jezusa ofiarującego się za grzechy świata, a Abraham - figurą Boga Ojca dokonującego ofiary ze swojego Syna. Również występujący w tej historii baranek poświęcony zamiast Izaaka, stał się mesjańskim symbolem. Scena akedah była bardzo ważna dla wyrażenia duchowości epoki wczesnochrzescijańskiej $\mathrm{z}$ tego względu, że zawierała w sobie jednocześnie kombinację męczeństwa $z$ ocaleniem. Gotowość na męczeństwo Izaaka była bliska ówczesnemu chrześcijaństwu wyznającemu wiarę, że droga do wiecznego życia może prowadzić przez poświęcenie, ofiarę i śmierć. Ofiara Abrahama wystąpiła w malarstwie katakumbowym, na sarkofagach, na mozaikach, jak np. w prezbiterium kościoła San Vitale z Rawenny. W tym ostatnim, scena akedah została umieszczona na łuku jednej ze ścian, tuż obok przedstawienia Abrahama i Sary, przyjmujących w gościnie trzech aniołów pod dębami Mamre. lzaak klęczy na ołtarzu, Abraham trzyma go lewą ręką za głowę, zas prawą z nożem ma wzniesioną wysoko do góry. Tam jest również skierowana jego głowa dostrzegająca w chmurze Rękę Boga, zaś po lewej stronie patriarchy stoi baranek. Z kolei w sztuce katakumbowej przykladem tej sceny jest fresk $z$ tzw. „kubikulum sakramentow" w katakumbie św. Kaliksta w Rzymie, gdzie pojawiła się ona obok kompozycji przedstawiających m.in. chrzest Jezusa, rozmnożenie chleba i ryb oraz proroka Jonasza. Zarówno Abraham jak i Izaak 
Podobnie jak w Beth Alfa, w synagodze $\mathrm{z}$ Seforis kompozycja przedstawiająca akedah znajdowała się niedaleko od wejścia do głównej sali budynku. Stanowiła ona tam jedną z części całej kompozycji mozaiki, której tematyka podkreślała $z$ jednej strony chwałę Świątyni, a z drugiej duchowy splendor synagogi jako miejsca przebywania Tory i Boskiej Obecności (Szekiny) ${ }^{28}$. Wskazywała ona na obecność Boga, który wybrał Abrahama, dał mu syna, a polecając złożyć go w ofierze poddał próbie, $\mathrm{z}$ jakiej wyszedł on zwycięsko. Podobnie stało się z Izaakiem, który przez samą gotowość na ofiarę został męczennikiem wiary, a dzięki łasce i miłosierdziu Boga byl przedmiotem Jego ocalenia.

\section{PROROK DANIEL W JASKINI LWÓW W SZTUCE SYNAGOGALNEJ}

Przedstawienie proroka Daniela w jaskini lwów jest kolejnym typem sceny męczeństwa i ocalenia w sztuce synagogalnej późnego antyku. Jak to zostalo już wspomniana na wstępie, jej wyobrażenia pochodzą z mozaiki VI-wiecznej synagogi $\mathrm{z}$ Na'aran $\mathrm{w}$ Judei, $\mathrm{z}$ reliefu bazaltowego ortostatu znalezionego w miejscowości 'En Samsam w Golanie i prawdopodobnie $\mathrm{z}$ mozaiki synagogi z Susija w Judei.

Daniel należał do największych proroków w historii Izraela ${ }^{29}$. Dużą część swojego życia spędził on na dworze królów babilońskich: Nebukednasera i Baltazara, a po upadku tego ostatniego u boku króla perskiego Dariusza. Historia wrzucenia proroka do jaskini $\mathrm{z}$ lwami wiązała się $\mathrm{z}$ tym ostatnim władcą i była wynikiem intrygi niektórych dworzan zazdrosnych o pozycję

zostali tam wyobrażeni w pozycji orantów. Powyższa scena wystąpila również $w$ katakumbie Via Latina, obok innej przedstawiającej Mojżesza otrzymującego tablice Dekalogu. W przypadku sztuki sarkofagowej przykładem tej ikonografi jest relief sarkofagu z bazyliki Św. Ambrożego w Mediolanie, gdzie mały Izaak (podobnie jak na mozaice z Rawenny) klęczy na skale przed swoim ojcem, czekając na zagładę z jego ręki. Na niektórych chrześcijańskich zabytkach Izaak został przedstawiony jako dorosły mężczyzną, co było wynikiem oddziaływania pewnej żydowskiej tradycji mówiącej o tym, że w chwili swojej ofiary miał on 37 lat. Takiego Izaaka widzimy na przykład na naczyniu szklanym z Bolonii i Trieru. W tym ostatnim przypadku, podobnie jak w sztuce synagogalnej, z chmury wynurza się Boska Ręka symbolizująca nadprzyrodzoną interwencję. Podobna "ręka" pojawiła się na malowidle grobowca z El Bagawat. W obu przypadkach Abraham wystąpil z nożem w ręku, stojąc nad postacią swojego syna znajdującego się w pobliżu ołtarza, zaś Boska Ręka ocalająca życie Izaaka stanowila przeciwieństwo ręki patriarchy, która miała przynieść śmierć.

${ }^{28}$ Po zniszczeniu Świątyni, synagoga stała się jej duchową i sakralną spadkobierćzynią, por. S. Fine, From Meeting House to Sacred Realm: Holiness and the Ancient Synagogue, w: Sacred Realm. The Emergency of the Synagogue in the Ancient World, red. S. Fine, New York - Oxford 1996, 21-47.

${ }^{29}$ Por. Encyclopaedia Judaica, hasło: „,Daniel”; J.B. Doukhan, Wizja przysztości w starożytnej księdze. Mq̨drość i wizje żydowskiego księcia na wygnaniu, tlum. J. Kauc, Warszawa 2001. 
Daniela w państwie medo-perskim ${ }^{30} . \mathrm{Z}$ drugiej strony stanowiła ona konsekwencję wierności proroka swojemu Bogu i Jego prawu.

Jak to opisuje szósty rozdział Księgi Daniela, wskutek intrygi mającej na celu skłonienie proroka do porzucenia czci swojego Boga na rzecz kultu posągu króla, został on wrzucony na pożarcie lwom. W jaskini ze zwierzętami Daniel spędzil całą noc, ale $w$ tym czasie one nic mu nie zrobiły, ze względu na interwencję anioła Bożego. W ten sposób Bóg wynagrodził wiarę Daniela, pokazując wszystkim na czele z królem Dariuszem, że był on niewinny. W skutek tych wydarzeń król kazał wydać dekret w całym swoim państwie, oddający część Bogu i mówiący, że: „[...] jest On Bogiem żyjącym i trwa na wieki. On ratuje i uwalnia, dokonuje znaków i cudów na niebie i na ziemi. On uratował Daniela $\mathrm{z}$ mocy lwów"31.

1. Scena z Danielem wśród lwów z synagogi w Na'aran i Susija. W synagodze z Na'aran mozaika wyobrażająca Daniela wśród lwów została umieszczona w górnym panelu, przedstawiającym symboliczny portal Świątyni lub jej Miejsca Najświętszego (devir) ${ }^{32}$. Środkowa część tej mozaiki zawiera znaki zodiaku z Heliosem na rydwanie w środku, natomiast najdłuższy i najniżej leżący panel - koła i oktościany mieszczące w sobie wizerunki różnych zwierząt.

Kompozycja przedstawiająca Daniela w jaskini lwów jest częściowo zachowana (ryc. 54$)^{33}$. Z postaci proroka przetrwały jedynie ręce, lwom zaś brakuje głów i przednich części korpusów, a u jednego z nich także przednich nóg: Daniel stoi w pozycji oranta. Wyobrażenia lwów różnią się od siebie; jeden z nich ma ogon opuszczony do dołu, zaś drugi ogon podniesiony do góry. Pomiędzy prorokiem a lwem stojącym od niego na prawo, znajduje się hebrajska inskrypcja zawierająca słowa: „Daniel” i „szalom”. Poniżej postaci człowieka, po jego lewej stronie wiđnieje też inskrypcja dedykacyjna w języku aramejskim.

Niewiele natomiast zachowało się z mozaiki przedstawiającej prawdopodobnie scenę z Danielem wśród lwów, zlokalizowanej w zachodniej części synagogi z Susija ${ }^{34}$. Tutaj stopień zniszczenia jest tak wielki, że z całości zachował się jedynie fragment hebrajskiej inskrypcji z dwoma ostatnimi literami imienia proroka: [Dani]el.

Jak podkreślają niektórzy badacze, umieszczanie sceny męczeństwa proroka Daniela w jaskini lwów na mozaikach tych synagog miało swoje głębokie

${ }^{30}$ Por. Dn 6, 2-16. Inna apokryficzna wersja tego wydarzenia został opisana w 14 rozdziale tej księgi.

${ }^{31}$ Dn 6, 26-29.

32 Por. R. Hachlili, Ancient Jewish Art and Archaeology in the Land of Israel, Leiden 1988, 294n; J. Naveh, Ancient Synagogue Inscriptions, w: Ancient Synagogues revealed, s. 136.

${ }_{33}$ Por. Hachlili, art. cyt., fig. 34.

${ }^{34}$ Por. tamże, s. 295; J. Gutmann (ed.), Ancient Synagogues. The State of Research, Chico CA 1981, 126. 
symboliczne znaczenie wskazujące na to, że Bóg jest wszechmogący i jest sprawcą jego ocalenia ${ }^{35}$. Ratując Daniela mógł on zbawić każdego wierzącego chroniącego się pod Jego „skrzydła”. Będąc bohaterem wiary, prorok ten stanowił przykład całkowitego poddania się woli Bożej i doskonałego zaufania Bogu. W ten sposób był on źródłem duchowej inspiracji dla Żydów na przestrzeni niemal wszystkich wieków ${ }^{36}$. $\mathrm{Z}$ drugiej strony, prorok Daniel mógl również personifikować cały naród Izraela, zmagający się z różnymi historycznymi przeciwnościami i nierzadko walczący o przetrwanie w swoich dziejach ${ }^{37}$.

\section{Relief $z$ Danielem wśród lwów na reliefie ortostatu $z$ 'En Samsam} w Golanie. Kolejny przykład ilustrujący historię Daniela w jaskini lwów, pochodzi z reliefu bazaltowego bloku odnalezionego w miejscowości 'En Samsam w Golanie (ryc. 55) ${ }^{38}$. Relief ten zdobi bok ortostatu, którego przednia część ma kształt lwiego torsu, stanowiąc pierwotnie bazę pod pomieszczenie na Torę w jednej z synagog. Był to budynek $z$ 'En Samsam albo z 'En Naszut, bądź Ghadarije - miejscowości leżących w pobliżu tej pierwszej. Zabytek ten jest obecnie przechowywany w Muzeum Archeologicznym Golanu w Kacrin.

W środkowej części reliefu wyobrażona została postać mężczyzny (ryc. 56). Po jego lewej stronie stoi lew $\mathrm{z}$ opuszczonym ogonem, a jego łeb znajduje się blisko glowy człowieka. Po prawej stronie widać lwicę z podniesionym ogonem i odrzuconą do tyłu głową, zaś do jej brzucha wczepione jest lwie szczenię. Mężczyzna stoi w pozycji oranta. Jego lewa ręka spoczywa na paszczy lwa, uniemożliwiając mu atak i pożarcie, natomiast prawa, większa ręka uniesiona jest w geście modlitwy i błogosławieństwa. Po zewnętrznej stronie lwów stoją orły, a ten po lewej stronie trzyma w dziobie kiść winogrona. Człowiek jest przepasany pasem, wyraźnie pogrubionym w stosunku do reszty ciała. Oryginalnie relief został pokryty kolorem czerwonym, natomiast jego tho - białym.

Cała kompozycja, jak i jej poszczególne motywy, charakteryzują się wielowar-stwością i głębią symbolizmu. Centralną postacią jest niewątpliwie prorok Daniel, o czym świadczą lwy stojące po jego bokach. W głębszej perspektywie wydaje się jednak, że jest to ktoś więcej niż Daniel, a sama postać proroka mogła posłużyć autorowi tego reliefu do przekazania bardziej wieloznacznych

35 Por. Goodenough, Jewish Symbols, II, s. 129

36 Por. przyp. 8.

${ }^{37}$ Por. A. Ovadiah, Art of the Ancient Synagogues in Israel, w: Ancient Synagogues. Historical Analysis and Archaeological Discovery, ed. D. Urman - P.F.M. Flesher, Leiden - New York - Köln $1995,310$.

${ }^{38}$ We wtórnym miejscu swojego użytkowania, por. Hachlili, art. cyt., s. 322, pl. 26; Z. Ma'oz, The Art and Architecture of the Synagogue of the Golan, w: Ancient Synagogues revealed, s. 111n. Relief $\mathrm{z}$ ortostatu w En Samsam jest również przedmiotem artykułu: P. Szkołut, Prorok Daniel w jaskini lwów na reliefie z En Samsam w Golanie. Interpretacja przedstawienia, „Folia Archeologica Universitatis Lodziensis" 24 (2004) 93-125. 
treści. Na przykład ręka człowieka zamykająca paszczę lwa jest w swojej zewnętrznej formie jego ręką, ale w swoim ukrytym znaczeniu mogła ona być symboliczną "ręką" anioła, który jak czytamy „zamknął paszczę lwom” (Dn $6,23)$. Z kolei same lwy zostały tu obdarzone ambiwalentną symboliką: samiec wyraża zagrożenie śmiercią, natomiast samica $\mathrm{z}$ lwiątkiem - życie, macierzyństwo i płodność. Dalej, orły asystujące całej scenie, pełnią jakby straż i ochronę w stosunku do człowieka. Jeden $z$ nich trzyma winogrono - symbol nagrody za męczeństwo i za gotowość ofiarowania swojego życia. Orły mogą tutaj symbolizować Bożą opatrzność albo pośrednio anioły, które miały za zadanie chronić proroka przed śmiercią. Taka interpretacja byłaby zgodna $\mathrm{z}$ literaturą biblijną, talmudyczną i mistyczną judaizmu, gdzie orzeł symbolizował działanie Boga wobec narodu wybranego, Jego moc i opatrznośćc ${ }^{39}$. Trzeba tu również dodać, że orzeł był równicż bardzo popularnym motywem w późnoantycznej sztuce synagogalnej ${ }^{40}$.

Powyższe przedstawienie proroka Daniela mogło stanowić wyraz potocznej, ludowej wiary w nadnaturalną moc tego proroka, będącego żydowskim herosem, podobnym do Samsona lub Eliasza ${ }^{41}$. Interpretacja symbolizmu tej sceny jest więc związana $z$ nadprzyrodzoną siłą człowieka, wyrażoną mocą jego rąk, z których jedna zamykała paszczę lwa (symbolizując pokonanie śmierci), zaś druga niejako blogosławiła lwicy $z$ lwiątkiem. Idąc dalej tym tokiem myślenia trzeba przyznać, że władza prezentowana na reliefie $z$ 'En Samsam nie jest dana żadnemu czlowiekowi, dlatego osoba wyglądająca niczym prorok Daniel, wyobrażałaby supernaturalną postać, którą w starożytnej tradycji żydowskiej mógł być tylko Mesjasz. Prawdopodobieństwo takiej interpretacji potwierdza pas umieszczony na biodrach człowieka. Jest to zapewne ten sam pas, o którym pisze prorok Izajasz, mówiąc o nadejściu mesjańskiego króla:

„I wyrośnie różdżka z pnia Jessego, wypuści się odrośl z jego korzeni. I spocznie na niej Duch Pański, duch mądrości, i rozumu, duch rady i męstwa, duch wiedzy i bojaźni Pańskiej [...]. Sprawiedliwość będzie mu pasem na biodrach, a wierność przepasaniem jego lędźwi” (Iz 11, 1-9) ${ }^{42}$.

W innych rozdziałach Księgi proroka Izajasza dowiadujemy się, że Mesjasz miał być również męczennikiem „który poniesic grzechy wielu” (Iz 53,12), co

${ }^{39}$ Por. Wj 19, 4; Pwt 32, 11; Ez 1, 10; 10, 14; Iz 40, 31; Ps 103, 5; AssMos 10 (W. J. Ferrar, The Assumption of Moses, London 1917,36n); Paralipomena Jeremiae (R.H. Charles, The Apocrypha and Pseudoepigraphica of the Old Testament in English, Oxford 1913); The Babilonian Talmud, ed. I. Epstein, London 1935 „Sanhedrin” 92a, Hagigah 13b; Midrash Rabbah, ed. H. Freedman - M. Simon, Londyn 1939, Exodus (Beshallach) XXIII 13, s. 291; Zohar, ed. H. Sperling - M. Simon, London 1935, III „Jethro” (Exodus) 80a-b, s. 240n; V „Ha'azinu”, 298b, s. 383n.

${ }^{40)}$ Powyższy temat jest przedmiotem pracy doktorskiej autora niniejszego artykułu, która powstała w ostatnich latach na Uniwersytecie Łódzkim.

${ }^{41}$ Por. L. Ginzberg, The Legends of the Jews, vol.1-5, Philadelphia 1968.

42 Tlum. z Biblii Tysiaclecia. 
również odpowiadałoby męczeńskiej idei ukrytej w powyższym reliefie z Golanu. Podobnie jak w przypadku mozaiki z Danielem z synagogi w Naaran (ryc. 54), interpretując postać $\mathrm{z}$ tego reliefu, można ją również odczytać jako personifikację narodu Izraela, zagrożonego przez wrogów, zmagającego się $\mathrm{z}$ nimi i szukającego swojego ocalenia w Bogu ${ }^{43}$.

Relief ortostatu z 'En Samsam należy do najciekawszych zabytków późnoantycznej sztuki żydowskiej. Zawiera on w sobie głębię symbolizmu, wyrażoną przez historyczną postać proroka Daniela oraz poprzez motywy lwów i orlów. W przeciwieństwie do mozaiki z Na'aran, wyobrażającej Daniela jako oranta powierzającego swoje życie Bogu, mężczyzna na reliefie z 'En Samsam przedstawia supernaturalną postać, o heroicznym lub mesjanistycznym charakterze. Postać ta utożsamiana z prorokiem Danielem, odegrała również ważną rolę w tradycji i sztuce chrześcijańskiej ${ }^{44}$.

43 Por. przyp. 32.

44 Ze względu na swój martyriologiczny i zbawczy charakter historia proroka Daniela w jaskini lwów cieszyła się dużą popularnością we wczesnym chrześcijaństwie. Jak pisał Charles R. Morey, wedle opinii Ojców Kościoła, prorok Daniel wśród lwów symbolizował „zmartwychwstanie, Eucharystię, modlitwę za zmarłych, pasję Chrystusa oraz stanowil przykład nieugiętości w męczeństwie" (Ch.R. Morey, Early Christian Art: An Outline of the Evolution of Style and Iconography in Sculpture and Painting from Antiquity to the Eight Century, Princeton 1942, 61). Ikonograficznym tego wyrazem są przedstawienia Daniela w malarstwie katakumbowym, na sarkofagach i na innych obiektach. Na przykład na wapiennej plycie (lac. antemensale) z kościoła w Rasm-el Qanatiz w Syrii z VI wieku, prorok zostal przedstawiony w pozycji oranta niczym mityczny „Pan Zwierząt”, nawiązujący niejako do idei Mesjasza władającego nad całą naturą i światem. Jego wyobrażenie na tym zabytku jest więc bliskie postaci Daniela z opisanego powyżej ortostatu z Golanu. W przeciwieństwie do orłów, na reliefie z Syrii wystąpiły pawie, z których jeden trzymał ogromną kiść winogrona, zaś drugi gałązkę cyprysu. Na obszarze samej Palestyny wyobrażenie Daniela wśród lwów wystąpiło na malowidle chrześcijańskiego grobowca z Lohamei haGeta’ot, znajdującego się na północ od Akko. Takie umiejscowienie tej sceny w kontekście sepulkralnym wskazywaloby na połączenie jej symboliki z ideą zmartwychwstania oraz modlitwy za zmarlych. Podobne znaczenie mogly mieć przedstawienia Daniela wśród lwów na sarkofagach. Przykładem tego jest relief $z$ tzw. ,sarkofagu dziecka” z katakumby $\delta w$. Kaliksta w Rzymie, datowany na IV wiek n.e., gdzie Daniel został wyobrażony jako nagi młodzieniec, pomiędzy miniaturowej wielkości lwami, sięgającymi mu zaledwie do połowy ud. Za lwami stoją dwaj mężczyźni, a ten znajdujący się po prawej stronje jest interpretowany jako prorok Habakuk. Scena ta dotyczy więc historii Daniela, zapisanej w deuterokanoniczym 14 rozdziale Księgi Daniela (Dn 14, 23-42). W sztuce wczesnochrześcijańskiej prorok Danjel wśród lwów był wyobrażany w pozie oranta, analogicznie do sztuki żydowskiej. W tych ikonograficznych kontekstach uderzająca jest zbieżność symbolicznego wyrazu tej sceny, ściśle powiązanego z ideologią obu religii. Jednakże to, co przede wszystkim łączy te bliźniacze przedstawienia stanowi fakt przejawiania się w nich idei mẹczeństwa i ocalenia, bliskich duchowości judaizmu i chrześcijaństwa. 


\title{
THE SCENES OF MARTYRDOM AND SALVATION IN LATE ANTIQUE SYNAGOGUE ART
}

\author{
(Summary)
}

The aim the article "The Scenes of Martyrdom and Salvation in Late Antique Synagogue Art" is presentation of all iconographical examples of these scenes appearing in Jewish art of late Antiquity. There are two types of them: one is showing the sacrifice of Abraham and another the prophet Daniel in lions' den. These imaginations belong to a broader range of so called ,salvations scenes”, which decorated mosaics, relieves and paintings of many synagogues, as well as churches and Christian catacombs.

First and foremost the scene with the sacrifice of Abraham (akedah) adorned a wall of the famous synagogue in Dura-Europos. It was pictured on the right side of the panel above the niche for Torah shrine (fig. 51), aside the portal of the Temple in the centre and the menorah on the left. Izaak is lying on the altar, Abraham is holding a knife in his right hand, while from the sky it is appearing the Divine Hand, symbolizing God's intervention resulting in the offering of a ram instead of Izaak.

Other scene showing akedah is found on the lowest part of the mosaic in the synagogue of Beth Alfa (fig. 52). Abraham is depicted on the right side close to the altar with burning fire. He is holding tiny Izaak in his left hand and a big knife in the right. His servants with the ass are on the left, and in the middle the ram is tied to a bush. Above it the Divine Hand is emerging from the cloud. On the mosaic, there are also written some Hebrew inscriptions with names and biblical citations.

The third example of the sacrifice of Abraham was imagined on the partially preserved synagogue mosaic in Sefforis in Galilee (fig. 53). It is divided in seven rows, where the sixth presents the sacrifice of Abraham and the seventh the visit of three angels at Abraham under the oaks of Mamre. The panel with akedah is divided in to parts: the left part is showing the patriarch's servants with the ass and the right, scarcely preserved part pictures only a ram tied to a bush and a couple of sandals on the left side. So the cssential scene of the offering od Izaak was originally located in the middle and right side of this panel.

The presence of the above mentioned scene in the synagogue art was a result of its importance for the Jewish piety throughout ages. In this tradition Izaak has played a role of the martyr offering his life to God. Izaak became so a figure of Israel willing to bear offerings in its history. His binding could have also symbolized this nation's bondage among other nations. The akedah tradition underlay the faith of Abraham and his obedience to God's will. On the other hand, it has constantly reminded of God's providence, mercy and salvation. By setting this scene on synagogue mosaics, Jews were learned of some of the most essential spiritual messages of Judaism.

The offering of Izaak becamc one of the most popular composition in early Christian art. Its theological message combining martyrdom with salvation was very 
close to the spirit of early Christianity. In its tradition Izaak became a type of Messiah offering himself for the sins of the mankind. It is a reason the akedah scene belonged to the broad range of scenes depicting the Old and New Testament histories, decorating catacombs, churches and sarcophaguses among others.

Another scene of martyrdom and salvation concerns the history of Daniel in the

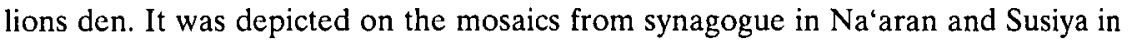
Judea, and on a basalt orthostat from En Samsam in Golan.

In the $\mathrm{Na}$ aran synagogue this scene decorated the upper panel of mosaic (fig. 54), that was put under the imagination of the Sacred Portal, flanked by two menorah. The piece with Daniel is partly preserved; it shows the prophet in the „orant" posture and is accompanied by some inscriptions (e.g. "Daniel" and "peace"). In the following synagogue in Susiya nothing has left from the scene, despite two letters of Daniel's name. According to the opinions of some scholars, the presence of this composition in early Byzantine synagogues could symboized the Jewish nation's fate under the Christian rule.

Interesting presentation of Daniel comes from the relief of the basalt stone from En Samsam (fig. 55, 56), which primarily served as a base for the Torah shrine. It shows prophet in the "orant” position among a lion and a lioness with a cub. The man has a belt on his whips, while his left hand is closing the lion's mouth. On both sides of lions there are relieves of two eagles. This composition has many layers of the symbolic significance. By shutting the beast's mouth the man symbolically wins over death, while the eagles might symbolize the God's providence, reminding of an angel who saved the prophet (Dn 6,23). This presentation might have been an example of a popular belief in the supernatural powers of Daniel, shared by ancient Jews. However, by holding the belt that could symbolize ,the belt of justice", he might have been a prototype of Messiah described in Iz 11, 1-9. Finally, Daniel could also become a personification of Israel fighting for its survival in the history. Being a hero of faith and a martyr saved by God's power, Daniel was an example of total belief and obedience to God's will. Thus he and the story of his salvations in lions' den became a source of inspirations and piety for Jews throughout ages.

The above described scenes, which appeared both in Jewish and early Christian art, share similar symbolic expressions connected with the ideology of every of these religion formations. But foremost, these scene are akin each other because of the idea of martyrdom and salvation manifested there, that was close to the spirit of Judaism and Christianity of that age. 